University of Nebraska - Lincoln

DigitalCommons@University of Nebraska - Lincoln

Faculty Publications, Department of Psychology

Psychology, Department of

October 2003

\title{
Juror Sensitivity to the Cross-Race Effect
}

Jordan Abshire

Louisiana State University

Brian H. Bornstein

University of Nebraska-Lincoln, bbornstein2@unl.edu

Follow this and additional works at: https://digitalcommons.unl.edu/psychfacpub

Part of the Psychiatry and Psychology Commons

Abshire, Jordan and Bornstein, Brian H., "Juror Sensitivity to the Cross-Race Effect" (2003). Faculty Publications, Department of Psychology. 183.

https://digitalcommons.unl.edu/psychfacpub/183

This Article is brought to you for free and open access by the Psychology, Department of at DigitalCommons@University of Nebraska - Lincoln. It has been accepted for inclusion in Faculty Publications, Department of Psychology by an authorized administrator of DigitalCommons@University of Nebraska - Lincoln. 


\title{
Juror Sensitivity to the Cross-Race Effect ${ }^{1}$
}

\author{
Jordan Abshire ${ }^{2}$ and Brian H. Bornstein ${ }^{3,4}$
}

\begin{abstract}
Black and White mock jurors'sensitivity to the cross-race effect was investigated by varying the race of the eyewitness in a simulated murder trial of a Black defendant. Participants heard an audiotape of a trial after which they rendered a verdict and rated the credibility of the witnesses. White participants found the prosecution witnesses (including the eyewitness) more credible, and the defense witness less credible, than did Black participants; they were also more likely to find the defendant guilty. The Black eyewitness was perceived as more credible than was the White eyewitness, but eyewitness race had no effect on verdict. These results are consistent with the literature indicating that jurors of different races reach different verdicts, and also that jurors are relatively insensitive to factors that affect eyewitness testimony, such as the cross-race effect.
\end{abstract}

KEY WORDS: cross-race effect, own-race bias, juror race, juror decision-making

Eyewitness identifications are one of the main factors that jurors use to formulate their verdicts (Cutler \& Penrod, 1995), and misidentifications at the trial stage can mean the difference between imprisonment and freedom (Scheck, Neufeld, \& Dwyer, 2000; Wells et al., 1998). Much of the reason for juries' erroneous convictions based on faulty eyewitness identifications is that jurors are not very sensitive to the factors that determine eyewitness accuracy. For example, Cutler, Penrod, and Dexter (1990) conducted a study of mock jurors' sensitivity to issues in eyewitness identification. The participants were presented with police descriptions of identification conditions that included 10 independent variables related to issues in eyewitness identification. Some of these factors (e.g., weapon presence, retention interval) are known to have a significant and often considerable impact on eyewitness accuracy, whereas others, such as eyewitness confidence, are at best weakly predictive of accuracy (Cutler \& Penrod, 1995). Of the 10 factors, the only manipulation that affected participants' verdicts was the level of

\footnotetext{
${ }^{1}$ This research was conducted as an undergraduate honors thesis by the first author, under the supervision of the second author.

${ }^{2}$ Department of Psychology, Louisiana State University, Baton Rouge

${ }^{3}$ Department of Psychology, University of Nebraska-Lincoln

${ }^{4}$ Corresponding author: 238 Burnett Hall, Department of Psychology, University of Nebraska-Lincoln, Lincoln, Nebraska 68588-0308; e-mail: bbornstein2@unl.edu.
} 
confidence of the eyewitness. Other research has likewise shown that eyewitness confidence is the overriding determinant of the weight mock jurors give to eyewitness testimony (e.g., Lindsay, Wells, \& O’Connor, 1989; Wells, Ferguson, \& Lindsay, 1981). Thus, mock jurors tend to be influenced by a variable that is only negligibly predictive of eyewitness performance, while being uninfluenced by several variables that have a pronounced relation to eyewitness performance.

Cutler et al. (1990) did not assess mock jurors' sensitivity to the relationship between the eyewitness's race and the defendant's race. A common cause of misidentifications is the "own-race bias" or "cross-race effect" (CRE), which refers to the tendency for people of one race to be better at identifying members of their own race than members of another race (Brigham \& Malpass, 1985; Chance \& Goldstein, 1996). The CRE is quite robust (Anthony, Copper, \& Mullen, 1992; Bothwell, Brigham, \& Malpass, 1989; Meissner \& Brigham, 2001; Shapiro \& Penrod, 1986; Sporer, 2001), occurs across various racial pairings (Meissner \& Brigham, 2001; Ng \& Lindsay, 1994; Platz \& Hosch, 1988), and is widely accepted among eyewitness experts (Kassin, Tubb, Hosch, \& Memon, 2001).As the CRE is a reliable source of misidentifications, it is an important factor to address in the context of jury decisions based on eyewitness testimony.

Although the CRE influences eyewitness accuracy, much of the general population is unaware of it. For example, Kassin and Barndollar (1992), in a survey of laypersons' beliefs about the effects of various factors on eyewitness performance, found that only $58 \%$ of participants agreed that a CRE would occur for White eyewitnesses attempting to identify Black suspects (compared to $79 \%$ of the experts surveyed). This divergence between people's common intuitions, on the one hand, and the state of the science, on the other hand, reflects the often erroneous nature of potential jurors' general beliefs about factors that do and do not influence eyewitness memory (Brigham \& Bothwell, 1983; Deffenbacher \& Loftus, 1982; Yarmey \& Jones, 1983). These beliefs, even if empirically unjustified, can have significant implications for jurors' verdicts in eyewitness cases (Lindsay, 1994).

Despite the abundance of research that addresses the effect of eyewitness's race on measures of eyewitness performance (e.g., Meissner \& Brigham, 2001), the effect of an eyewitness's race on jury decisions has not been addressed. Only scant research has addressed the effect of any witness's race (other than the defendant's, who may of course testify as a witness). Memon and Shuman (1998) varied the race and gender of an expert witness at trial. The Black female expert witness was perceived as being the most persuasive, showing that there was no own-race bias in the predominantly White sample (239 White vs. 37 Black mock jurors). With respect to participants' own race, the Black mock jurors rated the expert witness - regardless of the witness's race and gender-as less qualified and less credible than did the White mock jurors (Memon \& Shuman, 1998). If Black jurors are indeed more skeptical of all witnesses, this result could have important consequences at trial.

Studies looking at the relationship between jurors' race and their verdicts have found that Black jurors tend to be less likely to convict than White jurors, in both actual (Broeder, 1959; Simon, 1967) and mock criminal trials (Bernard, 1979), especial- 
ly when the defendant is Black (King, 1993; Skolnick \& Shaw, 1997; Sommers \& Ellsworth, 2000; Ugwuegbu, 1979). Racial differences appear in civil trials as well, where Black mock jurors are more likely to reach a verdict for the plaintiff (Bornstein \& Ra$\mathrm{jki}, 1994)$. This pattern seems to reflect a belief among the majority of Black persons that the justice system (i.e., law enforcement and the courts) is discriminatory and biased (Brooks \& Jeon-Slaughter, 2001; Hagan \& Albonetti, 1982; Mann, 1993; Wortley, 1996), leading them to side with persons whom they perceive as up against the system - namely, criminal defendants and civil plaintiffs. For example, Wortley (1996) reported that $76 \%$ of Black participants believed the police treated Blacks differently from Whites, compared to $51 \%$ of White participants. Similarly, $60 \%$ of Blacks believed judges discriminated against Blacks, versus 38\% of Whites. This pattern generalized to perceived discrimination against all minority groups, not just Blacks.

In summary, the CRE is a phenomenon agreed upon by experts, but many prospective jurors are not aware of it or may misunderstand it. Previous research on potential jurors' knowledge of the CRE has employed predominantly White samples (Brigham \& Bothwell, 1983; Deffenbacher \& Loftus, 1982; Kassin \& Barndollar, 1992; Yarmey \& Jones, 1983). Black individuals' general distrust of the legal system (Hagan \& Albonetti, 1982; Wortley, 1996) may make them more sensitive to the influence of racial factors, such as the CRE, in legal contexts. Furthermore, even if jurors-Black or White - are aware of the CRE, they may not give it sufficient weight in their verdict determination. In addition, differences in verdict and witness perception exist between jurors of different races. For these reasons, research is needed that varies the race of the eyewitness for mock jurors of different races, in order to assess mock jurors' perception of the CRE and their use of it in reaching a verdict.

The independent variables in the present experiment were the race of the eyewitness (Black or White) and the race of the mock juror (Black or White); the race of the defendant was held constant. ${ }^{5}$ We predicted that there would be a main effect of mock jurors' race on their verdicts. On the basis of previous research in which White mock jurors treated Black defendants more harshly than did Black mock jurors (e.g., Skolnick \& Shaw, 1997; Ugwuegbu, 1979), the White mock jurors in the present study were expected to render more guilty verdicts. With respect to the perceived credibility of the witnesses, there are two possibilities. On the one hand, if Memon and Shuman's findings (Memon \& Shuman, 1998) generalize from expert witnesses to any witness, then Black mock jurors would rate all witnesses as less credible than would White mock jurors. On the other hand, if White mock jurors' harsher treatment of Black defendants reflects a more positive attitude toward the criminal justice system among White individuals than among Black individuals, especially regarding the treatment of minorities (Brooks \& Jeon-Slaughter, 2001; Hagan \& Albonetti, 1982; Wortley, 1996), then White mock jurors would rate prosecution witnesses as more credible than Black mock jurors; but the opposite pattern would be true for defense witnesses.

\footnotetext{
${ }^{5}$ An ideal experimental manipulation would vary the defendant's and even the victim's race as well. We limited our study to manipulations of the participant's and the eyewitness's race because our focus is on the effect of eyewitness factors on jurors' judgments, so these variables are most relevant to our primary research question.
} 
On the basis of the results of the Cutler et al. study in which mock jurors were insensitive to all factors that affect eyewitness testimony except for eyewitness confidence (Cutler et al., 1990) we did not expect a main effect of the race of the eyewitness on mock jurors' verdicts or credibility ratings. However, we did predict that mock jurors who were aware of the CRE would be affected more by the eyewitness's race than those who were not. Finally, we made no predictions concerning interactions between participant and eyewitness race for either the verdicts or the credibility ratings, based on a lack of research addressing both independent variables together.

\section{METHOD}

\section{Participants and Design}

The participants were 145 undergraduates, 80 of whom were White and 65 of whom were Black. Participants were randomly assigned to the two eyewitness (Black-White) conditions, creating four groups of 31-42 participants apiece. ${ }^{6}$

\section{Materials}

An audiotape of a murder trial was played on a tape player. The 22-min trial consisted of normal courtroom proceedings: judge's instructions, opening arguments, witness testimony (with direct and cross-examination), closing arguments, and jury instructions. The victim was killed following an argument at night outside a gym. The prosecution called an eyewitness, who identified the defendant in court as having committed the crime, and a police detective, who described how he found the gun used in the murder at the defendant's house and how he conducted the lineup. The defense argued that the eyewitness lineup was biased and that the eyewitness was unreliable, because he observed the crime from $75 \mathrm{ft}$ away, in poor lighting, and without his glasses. Finally, the defense called an alibi witness, who testified that she saw the defendant at his house (where she was visiting the defendant's roommate) both before and after the time at which the crime occurred; she believed that at the time of the murder, the

${ }^{6}$ Most participants (all of the Whites, and roughly two-thirds of the Blacks) were recruited from psychology courses $(N=125)$ and received extra course credit. To obtain roughly equal numbers of Black and White participants, 20 Black participants were also recruited from an African-American studies course (cf. Skolnick \& Shaw, 1997). Because of logistical constraints, all of these participants were run in the White eyewitness condition. To test for any effects of this nonrandom sampling procedure, one-way ANOVAs on the principal dependent variables were performed that included the following five groups: White participants/White eyewitness, White participants/Black eyewitness, Black participants/Black eyewitness, Black psychology participants/White eyewitness, and Black African-American studies participants/White eyewitness. As predicted, the omnibus $F$ tests were significant, but Tukey post-hoc comparisons showed that the responses of the Black participants in the White eyewitness condition did not differ as a function of recruitment method (i.e., psychology vs. AfricanAmerican studies course), $p \mathrm{~s}>$.7. Planned comparisons involving just these two groups likewise showed no significant differences: Verdict, $\chi^{2}=.68, \mathrm{p}>.4, \Phi=.15$; Verdict-strength, $F(1,29)=0.23, p>.6, \eta^{2}=.008$; Eyewitness Credibility, $F(1,29)=1.37, p>.2, \eta^{2}=.045$. The two groups of Black participants in the White eyewitness condition were therefore combined for purposes of analysis. 
defendant was upstairs alone. The prosecution argued that the defendant could have snuck out of the house, committed the crime, which occurred only a couple of blocks away, and returned to the house, all without this witness's knowledge.

During the trial, a picture of each trial participant was projected on a screen. The trial was pretested to ensure that the evidence of guilt was even-handed and to select photos for the Black and White eyewitness. For the pretest, 30 participants listened to the audiotape of the trial without the slides - and thus without knowledge of any individual's race - and rendered a verdict. The verdicts were evenly split between guilty and not guilty. The pretest participants also rated the attractiveness of several photos of Black and White males, all approximately the same age, on an 11-point scale (extremely unattractive to extremely attractive). The two photos (one Black and one White, both rated as somewhat attractive) that received the most similar attractiveness ratings were selected for use in the trial as the eyewitness photos.

\section{Procedure}

Small groups of participants were tested at a time. Participants were instructed that they were acting as jurors in a criminal trial and that at the conclusion of the trial they would render a verdict and answer a few questions about the trial. The experimenter then started the audiotape of the trial and projected the picture of the defendant onto the screen. When the tape reached the judge's instructions, the arguments of the attorneys, or the testimony of the witnesses, the experimenter projected the corresponding photo of that individual onto the screen. The victim was never shown. At the conclusion of the trial, the experimenter projected the defendant's picture onto the screen again and then turned off the projector.

The first response sheet requested a verdict of "guilty" or "not guilty," as well as a rating of the participants' confidence in their verdict $(1=$ not confident to $5=$ very confident). Participants next rated the following three items pertaining to each witness, on an 11-point ( -5 to +5$)$ scale: accuracy, credibility, and importance of the witness's testimony. The last sheet had 10 questions that asked the participants to indicate their beliefs about various aspects of eyewitness testimony. Embedded in the list was a question on the CRE: "A witness is (circle one) more likely/less likely/just as likely to correctly identify a member of his or her own race in a lineup than a member of a different race." The participants were also given a demographic questionnaire on which they indicated their gender, race, and whether they had previously served on a jury. Participants also indicated of what race they believed the victim to be (neither participants' own race nor the eyewitness's race affected their responses, $p \mathrm{~s}>.05$ ).

\section{RESULTS}

The three measures of witness credibility (accuracy, credibility, importance) were significantly intercorrelated (all $r \mathrm{~s}>.39, p \mathrm{~s}<.001$ ) and were therefore summed to form an overall credibility index for each witness $(\alpha \mathrm{s}>.77)$, which ranged from -15 to 15 . 


\section{Verdicts}

Overall, 57 participants (39.3\%) found the defendant guilty. A logistic regression was performed to analyze differences in verdict as a function of eyewitness and participant race. There was a significant relationship between mock jurors' race and their verdict $(B=1.43$, Wald $=6.53, p=.01)$ with $51.2 \%$ of the White mock jurors rendering a guilty verdict, versus $27.7 \%$ of the Black mock jurors. There was no significant relationship between the race of the eyewitness and participants' verdict $(B$ $=.82$, Wald $=2.01$ ): $33.8 \%$ of those in the White eyewitness condition and $45.6 \%$ of those in the Black eyewitness condition rendered a guilty verdict. The interaction was not significant, $B=.92$, Wald $=1.57$. Comparable results were obtained when participants' verdicts and their confidence in them were combined to create a continuous "verdict-strength" score (not reported here for the sake of brevity, but available from the corresponding author).

\section{Witness Credibility}

Mean ratings of the witnesses are shown in Table 1 . There was a main effect of participants' race on the credibility rating of the eyewitness, $F(1,140)=13.50, p$ $<.001, \eta^{2}=.088$. The White participants rated the eyewitness as more credible, with a mean rating of $6.69(S D=6.13)$, than did the Black participants, whose mean rating was $3.16(S D=5.82)$. There was also a main effect of the race of the eyewitness, $F(1,140)=7.04, p<.01, \eta^{2}=.048$, with the White eyewitness receiving a mean rating of $3.87(S D=6.52)$ and the Black eyewitness a mean rating of 6.27 $(S D=5.76)$. Additionally, there was a significant interaction, $F(1,141)=4.56, p$ $<.05, \eta^{2}=.032$. The effect of the race of the eyewitness was greater for Black than for White participants (see Table 1, Column 1). Simple effect tests revealed that Black participants found the Black eyewitness to be more credible than the White eyewitness, $t(1,62)=3.49, p<.01$, but there was no effect of the race of the eyewitness for White participants, $t(1,62)=.37$.

There was a similar pattern for credibility ratings of the other prosecution witness (see Table 1, Column 2). White participants rated the detective as somewhat more credible $(M=6.00, S D=6.14)$ than did Black participants $(M=4.15, S D=$

Table 1. Mean Credibility Ratings of the Witnesses

\begin{tabular}{cccc}
\hline Condition & Eyewitness $^{a}$ & Detective $^{a}$ & Alibi $^{a}$ \\
\hline Black Participants (Total) & $3.16(5.82)$ & $4.15(5.85)$ & $8.20(5.20)$ \\
Black Eyewitness & $5.42(4.61)$ & $5.15(6.03)$ & $7.76(6.11)$ \\
White Eyewitness & $.74(6.07)$ & $3.06(5.54)$ & $8.68(4.02)$ \\
White Participants (Total) & $6.69(6.13)$ & $6.00(6.14)$ & $6.36(5.42)$ \\
Black Eyewitness & $6.93(6.50)$ & $6.95(5.24)$ & $6.31(5.47)$ \\
White Eyewitness & $6.42(5.77)$ & $4.95(6.91)$ & $6.42(6.43)$ \\
Grand Total & $5.12(6.23)$ & $5.17(6.06)$ & $7.19(5.38)$ \\
\hline
\end{tabular}

Note. This credibility index sums three ratings on a scale that ranged from -5 to +5 , so that the composite index ranges from -15 to +15 .

${ }^{a}$ Values in parentheses indicate Standard Deviations. 
$5.85), F(1,141)=3.42, p<.07, \eta^{2}=.024$. There was also a main effect of the race of the eyewitness, $F(1,141)=4.20, p<.05, \eta^{2}=.029$, with those in the White eyewitness condition rating the detective as less credible $(M=4.10, S D=6.36)$ than those in the Black eyewitness condition $(M=6.14, S D=5.64)$. There was not a significant interaction, $F(1,141)<.01$.

There was an opposite pattern on the credibility rating of the alibi (defense) witness. The White participants rated the alibi witness as less credible $(M=6.36, S D=$ $5.42)$ than the Black participants $(M=8.20, S D=5.20), F(1,141)=4.31, \mathrm{p}<.05, \eta^{2}=$ .03 (see Table 1, Column 3). There was not, however, a main effect of the race of the eyewitness, $F(1,141)=.33$, nor was there a significant interaction, $F(1,141)=.20$.

\section{Cross-Race Belief}

The cross-race question embedded in the posttrial questionnaire asked whether participants believed witnesses were "more likely," "less likely," or "just as likely" to identify members of their own race correctly than members of another race in a lineup. For the purpose of analysis, "more likely" responses were coded "correct," and other responses were coded "incorrect." Participants' responses were regressed onto the variables of participant and eyewitness race. There was a significant main effect of participant race, $B=1.39$, Wald $=5.59, p<.05$, due to a greater proportion of correct responses among Black participants (43.55\%) than among White participants $(28.75 \%)$. Neither the main effect of eyewitness race nor the interaction was statistically significant, $B<1.24$, Walds $<2.73, p s \geq .1$.

To assess whether participants who were sensitive to the CRE were more likely to be influenced by the eyewitness's race than were participants who were insensitive to the effect, participants' cross-race belief, participant race, and eyewitness race were entered as independent variables in analyses of participants' verdicts and ratings of the eyewitness's credibility. If participants factored knowledge about the CRE into their verdicts, one would expect that "accurate belief" participants would render more guilty verdicts in the Black eyewitness condition-where the eyewitness was the same race as the defendant - than in the White eyewitness condition. On the other hand, "inaccurate belief" participants should be unaffected by eyewitness race. Participants' cross-race belief had a significant effect on neither measure nor did it interact significantly with the other variables, $p s>.1$. Thus, participants who were aware of the CRE were no more likely to take it into account when evaluating eyewitness testimony and reaching a verdict than participants who were unaware of the effect.

\section{DISCUSSION}

The hypothesis that White mock jurors would render more guilty verdicts than Black mock jurors was supported. This result is consistent with other studies in which Black mock jurors were more lenient than White mock jurors toward a Black defendant being tried for a violent crime (Bernard, 1979; Johnson, 1985; Skolnick \& Shaw, 1997; Ugwuegbu, 1979). Because the present study did not also vary the race of the 
defendant, we cannot know whether Black jurors would always be more lenient than White jurors, or merely favor defendants of their own race; prior research supports both possibilities (King, 1993; Sommers \& Ellsworth, 2000, 2001).

The hypothesis that there would be a main effect of participant race on the credibility of the eyewitness was also supported. The White participants found the eyewitness to be more credible than did the Black participants. This result supports Memon and Shuman's finding that Black mock jurors rated an expert witness as being less credible than did White mock jurors (Memon \& Shuman, 1998). These results could imply that Black jurors are just more skeptical of witnesses in general; however, the Black mock jurors in the present study rated the alibi witness as more credible, while also rating another prosecution witness (the detective) as less credible, compared to the White mock jurors.

This constellation of findings suggests that Black individuals view defense witnesses more favorably, but prosecution witnesses less favorably, than do White individuals. This explanation is supported by research showing that Black persons view the criminal justice system as more biased and discriminatory than do White persons, especially when, as in the present mock trial, the defendant is Black (Brooks \& JeonSlaughter, 2001; Hagan \& Albonetti, 1982; Wortley, 1996).

In the majority of cases, it is obviously desirable for jurors not to be influenced by an eyewitness's race-unless it has implications for that witness's reliability, as it does in the case of the CRE. In the present study, there was no effect of the race of the eyewitness on verdicts. This result is in line with previous research (e.g., Cutler et al., 1990; Lindsay, 1994) showing that mock jurors are generally insensitive to factors pertaining to eyewitness testimony other than eyewitness confidence. However, there was a main effect of the race of the eyewitness on his perceived credibility. Participants rated the eyewitness as more credible in the Black eyewitness condition, suggesting that perhaps they were aware of the CRE and, therefore, perceived the White eyewitness as less credible because of his race. One explanation for the failure of eyewitness race to exert an effect on verdicts is that there was other strong incriminating evidence against the defendant, namely, the discovery of the gun at his home. Future research should manipulate the strength of the other evidence to determine whether eyewitness race would have a greater effect as it becomes more central to the case.

It is also possible that the effect of eyewitness race on credibility would be mitigated by the deliberation process. Although some research suggests that group deliberation minimizes the effect of extralegal factors (e.g., Ellsworth, 1989), other studies have found comparable extralegal effects, both pre-and postdeliberation, for variables such as a plaintiff's injury severity (Greene, Johns, \& Bowman, 1999) and negative pretrial publicity (Steblay, Besirevic, Fulero, \& Jimenez-Lorente, 1999). Thus, it is hard to predict whether deliberation would offset the effect of eyewitness race; future research should address this possibility.

The main effect of an eyewitness's race on his credibility was qualified by an interaction with participant race, such that only Black participants perceived eyewitnesses of different races as varying in credibility. Black participants were also more likely than White participants to demonstrate an explicit awareness of the CRE on the postexperimental questionnaire. However, participants who were explicitly aware of 
the CRE were no more sensitive to variation in the race of the eyewitness than those who were unaware of the phenomenon. Furthermore, although Black participants discriminated between eyewitnesses of different races in evaluating the eyewitness's credibility, these differential credibility assessments did not translate into verdicts that differed as a function of eyewitness race (i.e., although Black participants were less likely than White participants to find the defendant guilty in both eyewitness conditions, their verdicts were the same whether the eyewitness was Black or White). This finding supports other research in which manipulations of the eyewitness's credibility had no effect on mock jurors' verdicts (e.g., Lindsay, 1994).

Race is an explosive issue in the criminal justice system generally (e.g., Cole, 1999; Fukurai, Butler, \& Krooth, 1993; Mann, 1993), and the present findings continue to support the notion that, indeed, "race matters." For example, they suggest that Black criminal defendants should prefer to have Black jurors. Also, they suggest that the race of the eyewitness in relation to the defendant may have an effect on the jurors' perceptions of the eyewitness's credibility, but this effect does not appear strong enough to influence their verdicts. The present findings demonstrate that, as with other factors that can affect the fallibility of eyewitness testimony (Cutler et al., 1990), potential jurors are not sensitive to the CRE.

\section{ACKNOWLEDGMENTS}

We are grateful to Jennifer Hunt and Richard Wiener for helpful comments on previous versions of the manuscript.

\section{REFERENCES}

Anthony, T., Cooper, C., \& Mullen, B. (1992). Cross-racial facial identification: A social cognitive integration. Personality and Social Psychology Bulletin, 18, 296-301.

Bernard, J. L. (1979). Interaction between the race of the defendant and that of jurors in determining verdicts. Law and Psychology Review, 5, 103-111.

Bornstein, B. H., \& Rajki, M. (1994). Extra-legal factors and product liability: The influence of mock jurors' demographic characteristics and intuitions about the cause of an injury. Behavioral Sciences and the Law, 12, 127-147.

Bothwell, R .K., Brigham, J. C., \& Malpass, R. S. (1989). Cross-racial identification. Personality and Social Psychology Bulletin, 15, 19-25.

Brigham, J. C. \& Bothwell, R. K. (1983). The ability of prospective jurors to estimate the accuracy of eyewitness identifications. Law and Human Behavior, 7, 19-30.

Brigham, J. C. \& Malpass, R. S. (1985). The role of experience and contact in the recognition of faces of ownand other-race persons. Journal of Social Issues, 41, 139-155.

Broeder, D. W. (1959). The University of Chicago jury project. Nebraska Law Review, 88, 744-760.

Brooks, R. R. W., \& Jeon-Slaughter, H. (2001). Race, income and perceptions of the U.S. court system. Behavioral Sciences \& the Law, 19, 249-264.

Chance, J. E., \& Goldstein, A. G. (1996). The other-race effect and eyewitness identification. In S. L. Sporer, R. S. Malpass, \& G. Koehnken (Eds.), Psychological issues in eyewitness identification (pp. 153-176). Mahwah, NJ: Erlbaum.

Cole, D. (1999). No equal justice. New York: The New Press.

Cutler, B., \& Penrod, S. D. (1995). Mistaken identification: The eyewitness, psychology, and the law. Cambridge: Cambridge University Press.

Cutler, B. L., Penrod, S. D., \& Dexter, H. R. (1990). Juror sensitivity to eyewitness identification evidence. Law and Human Behavior, 14, 185-191.

Deffenbacher, K. A., \& Loftus, E. F. (1982). Do jurors share a common understanding concerning eyewitness behavior? Law and Human Behavior, 6, 15-30. 
Ellsworth, P. C. (1989). Are twelve heads better than one? Law and Contemporary Problems, 52, $205-224$.

Fukurai, H., Butler, E.W., \& Krooth, R. (1993). Race and the jury. New York: Plenum.

Greene, E., Johns, M., \& Bowman, J. (1999). The effects of injury severity on jury negligence decisions. Law and Human Behavior, 23, 675-693.

Hagan, J., \& Albonetti, C. (1982). Race, class, and the perception of criminal injustice in America. American Journal of Sociology, 88, 329-355.

Johnson, S. L. (1985). Black innocence and the white jury. Michigan Law Review, 83, 1611-1708.

Kassin, S. M. \& Barndollar, K. A. (1992). The psychology of eyewitness testimony: A comparison of experts and prospective jurors. Journal of Applied Social Psychology, 22, 1241-1249.

Kassin, S. M., Tubb, V. A., Hosch, H. M., \& Memon, A. (2001). On the "general acceptance" of eyewitness testimony research: A new survey of the experts. American Psychologist, 56, 405-416.

King, N. J. (1993). Postconviction review of jury discrimination: Measuring the effects of juror race on jury decisions. Michigan Law Review, 92, 63-130.

Lindsay, R. C. L. (1994). Expectations of eyewitness performance: Jurors' verdicts do not follow from their beliefs. In D. F. Ross, J. D. Read, \& M. P. Toglia (Eds.), Adult eyewitness testimony (pp. 362-384). New York: Cambridge University Press.

Lindsay, R. C. L., Wells, G. L., \& O’Connor, F. J. (1989). Mock-juror belief of accurate and inaccurate eyewitnesses: A replication and extension. Law and Human Behavior, 13, 333-339.

Mann, C. R. (1993). Unequal justice. Bloomington, IN: Indiana University Press.

Meissner, C. A., \& Brigham, J. C. (2001). Thirty years of investigating the own-race bias in memory for faces: A meta-analytic review. Psychology, Public Policy, and Law, 7, 3-35.

Memon, A., \& Shuman, D. (1998). Juror perception of experts in civil disputes: The role of race and gender. Law and Psychology Review, 22, 179-197.

Ng, W., \& Lindsay, R. C. L. (1994). Cross-racial facial recognition: Failure of the contact hypothesis. Journal of Cross-Cultural Psychology, 25, 217-232.

Platz, S. J., \& Hosch, H. M. (1988). Cross-racial/ethnic eyewitness identification: A field study. Journal of Applied Social Psychology, 18, 972-984.

Scheck, B., Neufeld, P., \& Dwyer, J. (2000). Actual innocence. New York, NY: Signet.

Shapiro, P. N., \& Penrod, S. D. (1986). Meta-analysis of facial identification studies. Psychological Bulletin, 100, 139-156.

Simon, R. J. (1967). The jury and the defense of insanity. Boston: Little, Brown.

Skolnick, P., \& Shaw, J. I. (1997). The O. J. Simpson criminal trial verdict: Racism or status shield? Journal of Social Issues, 53, 503-516.

Sommers, S. R., \& Ellsworth, P. C. (2000). Race in the courtroom: Perceptions of guilt and dispositional attributions. Personality and Social Psychology Bulletin, 26, 1367-1379.

Sommers, S. R., \& Ellsworth, P. C. (2001). White juror bias: An investigation of prejudice against Black defendants in the American courtroom. Psychology, Public Policy, and Law, 7, 201-229.

Sporer, S. L. (2001). Recognizing faces of other ethnic groups: An integration of theories. Psychology, Public Policy, and Law, 7, 36-97.

Steblay, N. M., Besirevic, J., Fulero, S. M., \& Jimenez-Lorente, B. (1999). The effects of pretrial publicity on juror verdicts: A meta-analytic review. Law and Human Behavior, 23, 219-235.

Ugwuegbu, D. C. E. (1979). Racial and evidential factors in juror attribution of legal responsibility. Journal of Experimental Social Psychology, 15, 133-146.

Wells, G. L., Ferguson, T. J., \& Lindsay, R. C. L. (1981). The tractability of eyewitness confidence and its implications for triers of fact. Journal of Applied Psychology, 66, 688-696.

Wells, G. L., Small, M., Penrod, S. D., Malpass, R. S., Fulero, S. M., \& Brimacombe, C. A. E. (1998). Eyewitness identification procedures: Recommendations for lineups and photospreads. Law and Human Behavior, 22, 603-647.

Wortley, S. (1996). Justice for all? Race and perceptions of bias in the Ontario criminal justice system-A Toronto survey. Canadian Journal of Criminology, 38, 439-467.

Yarmey, A. D., \& Jones, H. P. (1983). Is the psychology of eyewitness identification a matter of common sense? In S. M. A. Lloyd-Bostock \& B. R. Clifford (Eds.), Evaluating witness evidence (pp. 13-40). Chichester: Wiley. 